\title{
Vulnerability zoning of earthquake disaster of Palu
}

\author{
Rusydi, $\mathbf{H}^{1}$, Rustan Effendi ${ }^{1}$, Rahmawati ${ }^{2}$ \\ ${ }^{1}$ Physics Department, Mathematics and Natural Sciences Faculty, Tadulako University, Palu, \\ INDONESIA \\ ${ }^{2}$ Geography Study Program, Social Sciences Department, Teacher Training and Education \\ Faculty, Tadulako University, Palu, INDONESIA \\ rusydiutd@gmail.com
}

\begin{abstract}
Palu is the area traversed by Palu-Koro faults and some small faults arround, which causes the frequent occurrence of earthquakes in Palu. Therefore, this study aims to determine the vulnerability of earthquake zone. Determination of this zona is one way to reduce the risk of earthquake disaster. This study used two methods, they are are descriptive and overlay weighted sum. For the overlay of data processing method using GIS application. The result of the study showed 45 district in Palu, 12 district located in low vulnerability zone, 11 district located in moderate vulnerability zone and 22 district located in high vulnerability zone.
\end{abstract}

\section{Introduction}

Natural disasters earthquakes are common in Palu because the area is traversed by the active faults of Palu-Koro. Any damages caused by the earthquake increases along with population growth rapidly and settlements increase in prone areas of earthquakes. Data Meteorology and Geophysics Agency (BMKG) Palu (2012) noted that not less than the 5 times a day occured minor earthquakes $(\leq 3 \mathrm{Mw})$ in Palu Valley, including Palu City).

The historical record of earthquakes since 1927, shows that there have been 8 (eight) times the destructive earthquake events in Palu valley. The eighth earthquake cause casualties are not less than 250 persons and property damage. Recently Earthquake that occurred at 18 February 2016 in Palu valley, Central Sulawesi caused casualties and considerable damage.

Casualties were reported by the National Disaster Management Agency (BNPB), 5 people died, 27 injured and 667 suffered minor injuries. A total of 527 houses were totally damaged, 311 units of houses were moderately damaged and 788 units were lightly damaged.

The description above shows that Palu Valley, especially Palu City is highly risky from the threat of earthquake disaster, so that the arrangement and management of the region should be pay attention to this.

Based on these explanations, it shows that Palu is very risky from the threat of earthquake disaster, so it's important to do a vulnerability analysis of the earthquake, the result of this study will produce a map with detail scale as a planning data of earthquake disaster risk reduction in this area. 


\section{Method}

This study uses primary and secondary data. Primary data is obtained from the survey results, while secondary data is obtained from the related institutions. Data collection techniques used in the survey field is an interview.

In making the earthquake vulnerability maps, Information source used for the analysis is coming from BPS reports (Province / Regency in figures, PODES, Susenan, PPLS and PDRB) and base map information from Bako surtanal (land uses, road networks and the location of public facilities). Indicator used in vulnerability analysis is primarily exposure information.

Technique data analysis used two methods: descriptive and overlay method weighted sum. Overlay technique is one of spatial analysis technique by overlapping the thematic maps to produce the vulnerability maps. The tool used is geographical information system software (GIS).

\section{Finding and Discussion}

Vulnerability can be defined as exposure multiplied by Sensitivity. Based on the results of descriptive analysis of the variables that affects the vulnerability of earthquake in research area, it shows:

\subsection{Social Vulnerability (Exposed Population Index)}

\subsubsection{Population Density.}

The result showed that 28 sub-districts out of 8 district which has the highest population density, or more than 1000 inhabitants $/ \mathrm{km}^{2}$, where the highest population density is in Ujuna sub-district Palu Barat while the lowest is in Poboya, Mantikulore sub-district. The higher of population density the higher the vulnerability of the region during an earthquake disaster.

Table 1. The population density of each sub-district at 2014

\begin{tabular}{llll}
\hline No & District & $\begin{array}{l}\text { Population } \\
\text { Percentage }\end{array}$ & $\begin{array}{l}\text { Population } \\
\text { Density per } \mathrm{km}^{2}\end{array}$ \\
\hline 1 & Palu Barat & 10,40 & 7302 \\
2 & Tatanga & 10,55 & 2592 \\
3 & Ulujadi & 7,32 & 668 \\
4 & Palu Selatan & 18,02 & 2498 \\
5 & PaluTimur & 18,09 & 8907 \\
6 & Mantikulore & 16,83 & 299 \\
7 & Palu Utara & 6,12 & 751 \\
8 & Taweli & 5,42 & 333 \\
\hline \multicolumn{3}{l}{ Source : BPS Palu, 2016 }
\end{tabular}

\subsubsection{The vulnerable groups with non-productive age.}

Age factor become an indicators that used to compute the social vulnerability besides overcrowding. Based on data obtained in Palu,. the population of productive age group 
(15-65 years) is much larger than the non-productive age group, 263.717 people (productive age) and 103.625 people (non-productive age).

Non-productive age becomes the most vulnerable age when disaster happens compared with the productive age group. This is because the population in the nonproductive age assumed that they did not get enough knowledge about preparedness of disaster and they have a week phisycal condition rather than the productive age. So it cannot reduce the risk if the earthquake occurred.

\subsubsection{Women Vulnerable Groups.}

Gender differences are concerned in this study. The female sex is considered to be the most vulnerable groups compare to men. It relates to the physical condition of women that is weaker than men. Data obtained revealed that ratio between men and women in Palu are 102. It means that there are 102 men per 100 women. The data showed that there is no big difference between the total number of population of men and women so that the level of vulnerability will be balance to women and men if disaster occurs.

\subsection{Physical Vulnerability}

\subsubsection{Density Settlement.}

Residential density is obtained by dividing them over wide and build area and divided by region (in hectares) and multiplied by the unit price of each parameter. there are five villages in Palu that have a high density of settlements they are: Ujuna sub-district, Baru sub-district, Kamonji sub-district, Siranindi sub-district, and Besusu Timur subdistrict.(Figure 1). An area with low of residential density is a region with low vulnerability level, and vice versa.

\subsubsection{Types of Building.}

Area with permanent conditions of the building construction is the region with a level of vulnerability that extremely vulnerable, because of the type of permanent contruction buildings are potentially suffered damage due to the earthquake disaster, rather than the non-permanent building construction. So that, the types of building constructions influenced by susceptibility. From eight subdistricts, $80 \%$ is permanent, $15 \%$ is semi permanent, and $5 \%$ is non permanent. Based on the result, Based on these conditions, the general types of buildings in Palu has a high degree of vulnerability. 


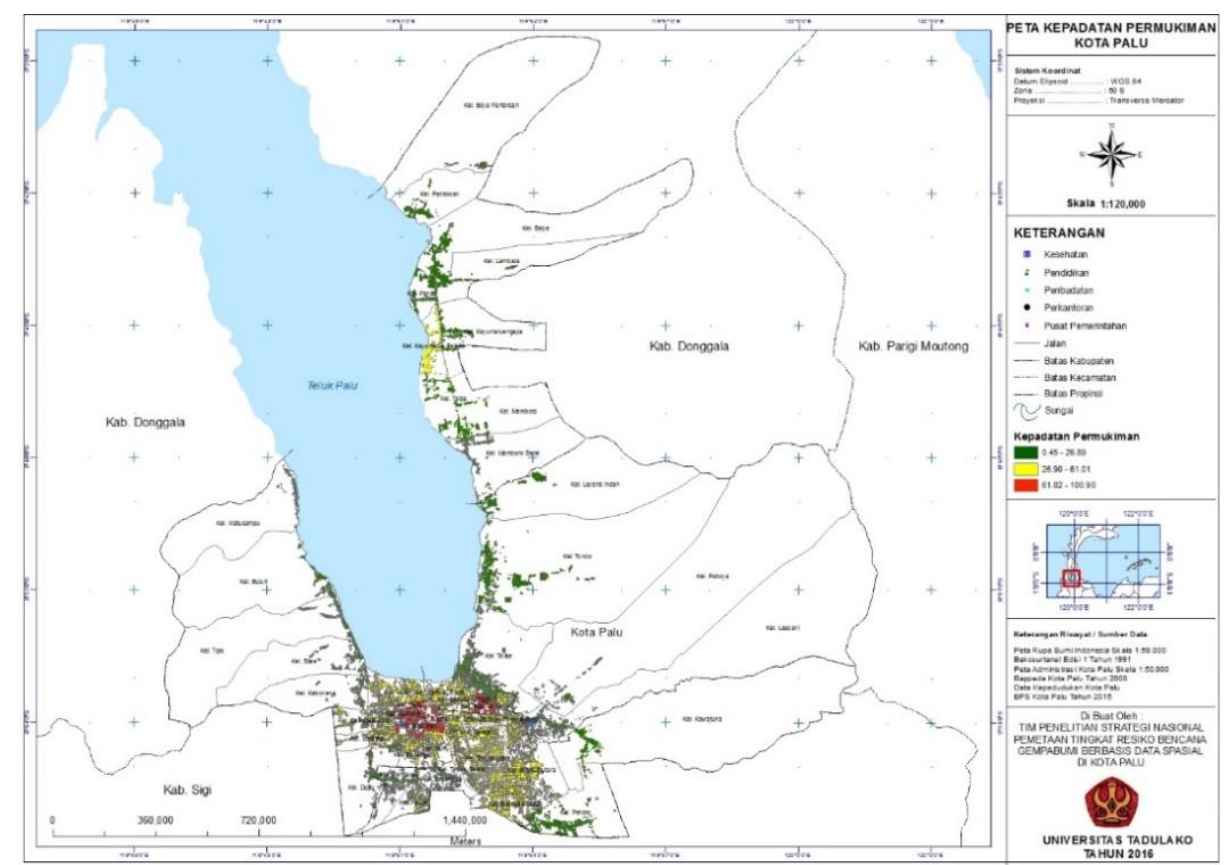

Figure 1. Density map settlements Palu

\subsubsection{The Availability of Public Facilities and Critical Facilities.}

Public facilities of five villages that have high density of settlements in Palu can be seen in (figure 2), such as office buildings, houses of worship, markets and schools, Meanwhile,critical facility is public health and hospital. Overall if this facility converted into vulnerability index it shows high grade of more than 1 billion.

\subsection{Environmental Vulnerability}

\subsubsection{The Land Use.}

Areas with the type of land use that built is more vulnerable to the earthquake disaster, compared to the other types of agricultural land use and plantation that has a low level of vulnerability. Depth types of land use shows the variety of group. It can be concluded that the type of land use influence the material damage at the same time when the disaster occurred (Figure 3). 


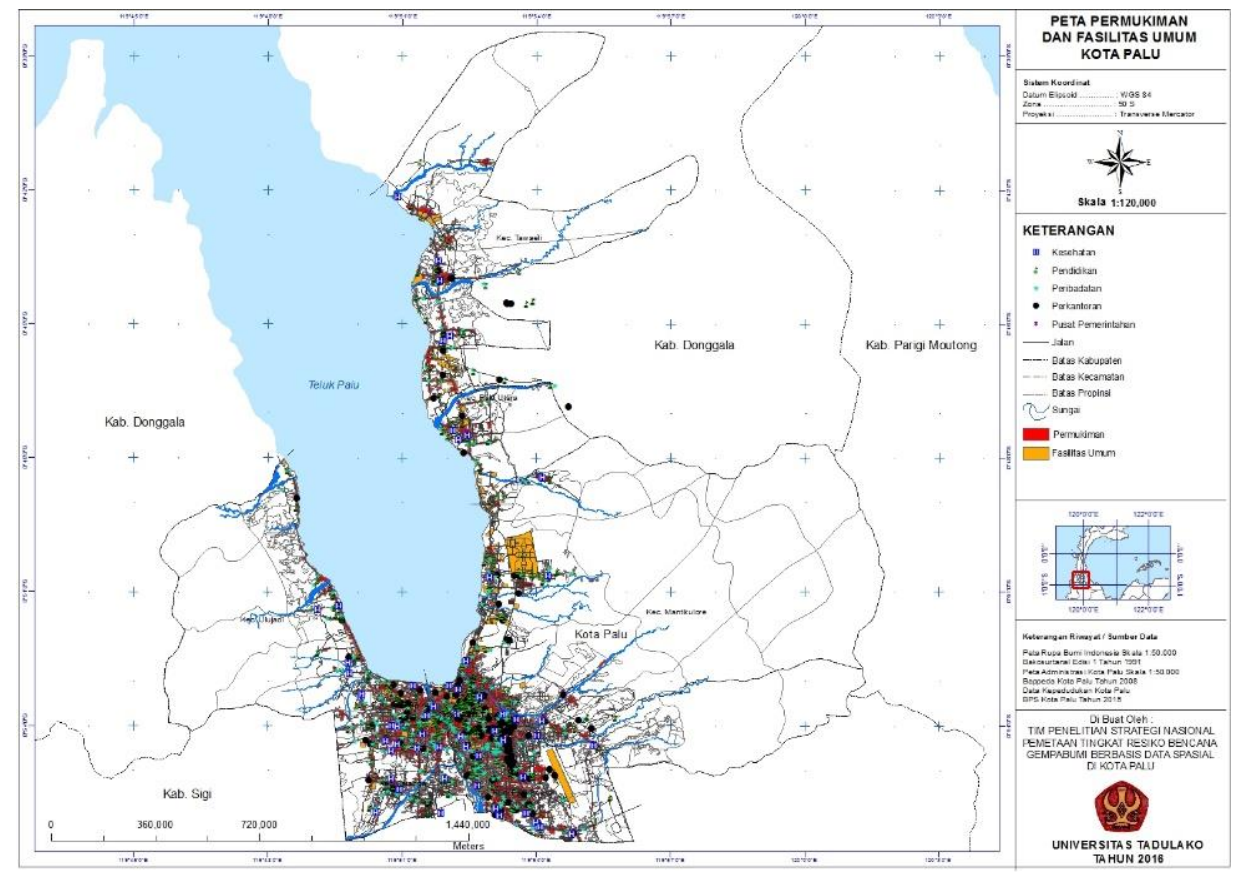

Figure 2. Settlement map and public facilities of Palu

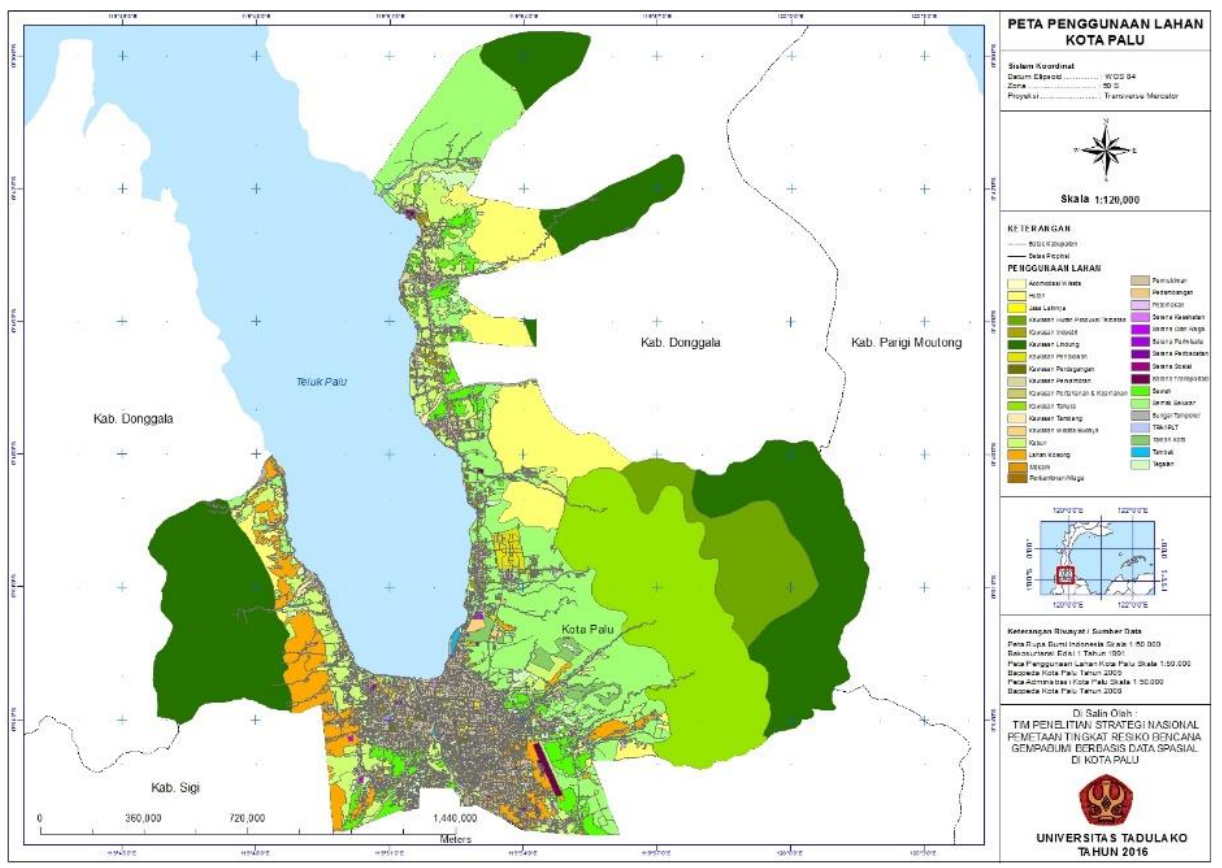

Figure 3. Land use map of Palu

\subsection{Vulnerability Analysis}

Obtaining the earthquake disaster vulnerability zone of Palu, the whole of the variables that have been described is weighted to determine how much the influence of susceptibility variable earthquake. A weighting refers to the general guidelines on disaster risk assessment (PERKA BNPB No. 02 Th.2012). The results weighting is overlaid using overlay technique weigthed sum. 
The result of vulnerability map indicates that 45 subdistricts in Palu, 12 subdistricts located in low vulnerability zone, 11 subdistricts located in moderate vulnerability zone and 22 subdistricts located in high vulnerability zone.

Analysis result of vulnerability level in the research area is presented in Figure 4 and Table 2 below:



Figure 4. Vulnerability map of Palu

Table 2. An area of vulnerability earthquake prone in district level

\begin{tabular}{lllll}
\hline No & District & \multicolumn{2}{l}{ Area (Ha) } \\
\cline { 3 - 5 } & & Low & Moderate & high \\
\hline 1 & Palu Barat & - & 39 & 700 \\
2 & Tatanga & 526 & 450 & 550 \\
3 & Ulujadi & 5225 & 1144 & - \\
4 & Palu Selatan & 369 & 425 & 1175 \\
5 & PaluTimur & - & 52 & 549 \\
6 & Mantikulore & 18230 & 997 & 13 \\
7 & Palu Utara & 2063 & 856 & 76 \\
8 & Taweli & 5923 & 125 & 20 \\
\hline
\end{tabular}

From the table above shows that most of the areas are in lower vulnerability. It caused by the lack of settlement level that is dominated by forest area. The high level of vulnerability area is located in densely populated areas with lots of numbers of infrastructure.

\section{Conclusions and Suggestion}

The results obtained show that 45 subdistricts in Palu, 12 subdistricts located in low vulnerability zone, 11 subdistricts located in moderate vulnerability zone and 22 
subdistricts located in high vulnerability zone. Based on this, need to do a study of the hazard and capacity to produce risk map

\section{References}

[1] Badan Meteorologi dan Geofisika, 2012, Berita Gempa, http//:www. bmg.co.id, diakses tanggal 20 Juli 2012

[2] BPS, 2012, Kota Palu Dalam Angka, Sulawesi Tengah

[3] De Leon, J.C.V. 2006. Vulnerability, A Conceptual and Methodological Review, Source 'Studies of the University : Research, Counsel, Education', Publication Series of UNU-EHS, Bonn.

[4] Rusydi, M.H., 1998., Studi Kegempaan di Daerah Sulawesi, Tesis, Universitas Gadjah Mada.

[5] Rusydi, M.H., 2011., Pengembangan Metode Aplikasi Citra Multispektral Untuk Kajian Risiko Bencana Gempabumi di Graben Palu, Disertasi, Universitas Gadjah Mada. 